UDC: 070

DOI: https://doi.org/10.32689/2617-

2224-2019-17-2-261-276

Stelmakhova Oleksandra Nikolaevna, master of marketing, analyst, founder of the first professional media platform for the media and experts Deadline, partner of the Ukrainian assembly of doctors of sciences in public administration, TOP-manager, tel.: +38(095)8520513,e-mail:a.stelmakhova@ gmail.com

ORCID: 0000-0002-2541-5742

\title{
Стельмахова Олександра
}

Миколаӥвна,

магістр з маркетингу, аналітик, власник

першої професійної медіа-платформи для 3МI та експертів Deadline, партнер Aсамблеї докторів наук з державного управління, ТОП-менеджер, тел.: +38 (095) 85205 13, e-mail: a.stelmakhova@gmail.com

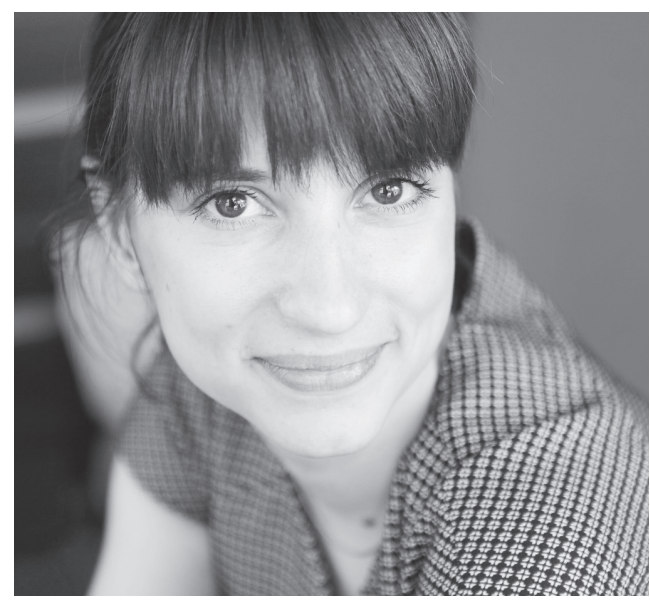

Стельмахова Александра Николаевна,

магистр маркетинга, аналитик, учредитель первой профессиональной медиа-платформы для СМИ и экспертов Deadline, партнер Ассамблеи докторов наук по государственному управлению, ТОП-менеджер, тел.: +38 (095) 85213 мая, е-таil: a.stelmakhova@gmail.com

\section{MEDIA OF UKRAINE: PROBLEMS AND OUTLOOK}

Abstract. The dynamics of up-to-date information transformations, the introduction of the most recent innovative technologies and the European integration vector of the national development, now more than ever help to improve the national media. However, the study of the outlined industry characteristics in the context of the social and communication paradigm has been confirmed by the existence and further development of negative trends that can include, among others, the following: 1) fragmentarity and low quality of journalistic education; 2 ) extremely large amount of media (glut) and low barriers to entry the market; 3) lack of independence; 4) fast food journalism trend; 5) use of intimidation linguistic elements in the middle of news and information texts; 6 ) imperfect media research; 7) daily disclosure of fake news; 8) lack of responsibility for poor-quality media content; 9 ) nonavailability of the media to implement effective marketing foreign concepts and practices; 10) archaic regulation of the media industry, and so on.

In terms of the subject of the article the question of legal basis of current media organizational work has been considered and the main issues have been con- 
firmed; the analysis of the fake content distribution has been carried out; media-catching phenomenon has been analyzed as well as the influence of VUCA concept on improving the current media of Ukraine. According to the research results, theoretical conclusions have been formulated and authors; proposals have been developed that would help to convince of the national competitiveness. The proposals can be summarized to the following:

1. To organize effectively the internal work of the media by using marketing trends and the latest innovative technologies;

2. To tighten control over the quality of content from editors;

3. To conduct qualitative fact-checking and struggle with fake news;

4. To make media catching an integral part of internal media processes;

5. To take an active part in formation of laws and increase cooperation with European experts in the media industry.

Keywords: media catching, fake news, VUCA concept, journalistic education, content quality, media marketing, internal organization of media, planning, key performance indicators (KPI).

\section{МЕДІА УКРАЇНИ: ПРОБЛЕМИ ТА ПЕРСПЕКТИВИ}

Анотація. Динаміка сучасних інформаційних трансформацій, впровадження новітніх інноваційних технологій та євроінтеграційний вектор розвитку держави як ніколи сприяють вдосконаленню вітчизняних медіа. Однак, дослідження характеристик окресленої галузі у контексті соціально-комунікаційної парадигми підтверджують наявність та подальший розвиток негативних тенденцій, до яких можна, серед іншого, віднести: 1) фрагментарність та низьку якість журналістської освіти; 2) надзвичайно велику кількість медіа (перенасиченість) та низький поріг входу на ринок; 3) управлінську несамостійність команд; 4) тренд “фаст-фуд” журналістики; 5) наявність системи мовних елементів залякування у середині новин та інформаційних текстах; 6) недосконалість медіа досліджень; 7) щоденне оприлюднення “фейкових новин”; 8) відсутність відповідальності за неякісний медіа контент; 9) неготовність ЗМІ до внутрішнього впровадження ефективних маркетингових закордонних концептів та практик; 10) архаїчність нормативно-правового регулювання медіа галузі та ін.

3 огляду на актуалізацію тематики розглянуто правові основи організаційної роботи сучасних медіа та підтверджено основні проблемні питання, проаналізовано інтенсифікацію поширення “фейкового” контенту та феномен "media-catching", схарактеризовано вплив концепції VUCA на покращення медіа-поля на території України в умовах сьогодення. За результатами проведеного дослідження сформульовано теоретичні висновки та розроблено авторські пропозиції, які б мали переконувати у конкурентоспроможності держави, а саме:

- ефективно організовувати внутрішню роботу ЗМІ з використанням маркетингових розробок та новітніх інноваційних технологій;

• посилити контроль за якістю контенту з боку редакцій; 
- проводити якісний “факт-чекінг” та боротьбу з “фейковими новинами";

• зробити “media catching” невід’ємною складовою організації внутрішніх процесів медіа;

- приймати активну участь у розробці законопроектів та посилити співробітництво з європейськими експертами у медіа галузі.

Ключові слова: media catching, фейкові новини, концепція VUCA, журналістська освіта, якість контенту, медіа маркетинг, внутрішня організація роботи ЗМІ, планування, показники ефективності KРI.

\section{МЕДИА УКРАИНЫ: ПРОБЛЕМЫ И ПЕРСПЕКТИВЫ}

Аннотация. Динамика современных информационных трансформаций, внедрение новейших инновационных технологий и евроинтеграционный вектор развития государства как никогда способствуют совершенствованию отечественных медиа. Однако, исследования характеристик этой области в контексте социально-коммуникационной парадигмы подтверждают наличие и дальнейшее развитие негативных тенденций, к которым можно, среди прочего, отнести: 1) фрагментарность и низкое качество журналистского образования; 2) чрезвычайно большое количество медиа (перенасыщение) и низкий порог входа на рынок; 3) управленческую несамостоятельность команд; 4) тренд “фаст-фуд” журналистики; 5) наличие системы языковых элементов запугивания в новостях и информационных текстах; 6) несовершенство медиа-исследований; 7) ежедневное обнародование “фейковых новостей”; 8) отсутствие ответственности за медиа-контент; 9) неготовность СМИ к внутреннему внедрению эффективных маркетинговых иностранных концепций и практик; 10) архаичность нормативно-правового регулирования медиа отрасли и прочее.

Учитывая актуализацию тематики были рассмотрены правовые основы организационной работы современных медиа и подтверждены основные проблемные вопросы, проанализированы интенсификация распространения “фейкового" контента и феномен "media-catching”, охарактеризовано влияние концепции VUCA на улучшение медиа-поля на территории Украины в нынешних условиях. По результатам проведенного исследования сформулированы теоретические выводы и разработаны авторские рекомендации, которые помогут убеждать в конкурентоспособности государства, а именно:

- эффективно организовывать внутреннюю работу СМИ с использованием маркетинговых разработок и новейших инновационных технологий;

- усилить контроль за качеством контента со стороны редакций;

- проводить качественный “факт-чекинг” и борьбу с “фейковыми новостями";

• сделать "media catching” неотъемлемой составляющей организации внутренних процессов медиа; 
- принимать активное участие в разработке законопроектов и усилить сотрудничество с европейскими экспертами в медиа отрасли.

Ключевые слова: media catching, фейковые новости, концепция VUCA, журналистское образование, качество контента, медиа маркетинг, внутренняя организация работы СМИ, планирование, показатели эффективности KPI.

Thesis statement. The study of the Ukrainian media industry in the socialcommunication paradigm context with the disciplinary approaches involvement, in particular, media-economic and media-sociological, provides an opportunity to state both negative tendencies of its formation and current development. According to the latest statistical data analysis results and own media space monitoring, it is possible to characterize the following phenomena that are currently characterized by the state of the national media industry, in particular:

1) fragmentarity and low quality of journalistic education, being established in 2016 by the 'Detector Media' specialists [1, p. 39-40] that currently has a tendency for both rapid and uncontrolled growth;

2) increasing the media number, meeting the legislative existence requirements, but actually only indirectly reminding effective and high-quality media. If comparing the mass media number in Ukraine per thousand people with other states, it exceeds the United States of America figure twice and the French Republic tenfold [2]. This is mainly due to the lack of requirements for the media market access, the content development organization, staffing and the final product quality. Today there is also media information 'clon- ing' that occurs at the expense of the existing registered official website, and the absence of both person, being responsible for news and creative skilled media team.

3) managerial independence of journalistic teams, especially among state and regional mass media, eliminating the possibility of purposefully optimizing all the self-organization and selfregulation processes of the whole media organization structure. Thus, according to the internal organizational structure research and indicated media effectiveness, it has been found that only $20 \%$ of them had commercial departments, $50 \%$ of editors worked for KPI, however, in general, they did not fully utilize the marketing component to achieve a higher level of productivity [3]. Thereby, processes, requiring both attention and optimization are intensified in order to form a stable basis for solving modern complex media tasks.

Moreover, we can talk about the 'fast food' journalism stirring in Ukraine, which 'pulls out' information from the context, and offers it to the audience without any processing and completion. This fact also indicates the processes of organization occurring in the media during material creation. In particular, the research results in 2018 are confirmed by the poor quality planning (lack of editorial plans), ineffective 
work time organization, slow content creation, the lack of business process automation and medium-term planning of media activities. According to the report on regional media 2018, the latter have no systematic organization of work, financial and strategic planning and key performance indicators for journalists [3].

Politicization, a high bureaucratization of domestic media, the increase in the intimidation elements and audience inhibition, taking place against the escalation backdrop by the Russian Federation are also among negative factors. Continued media content unification (monotony, stereotypeness, limited problem-thematic selection, genre imbalance), its constant repetition causes the artificial formation phenomenon appearance of audience media needs as a long-term media effect on the territory of our country. Therefore, one of the main media functions, cultural and educational, is almost completely replaced by market profitability and targeting the mass audience coverage [4, p. 118].

The above implies the necessity of introducing new approaches, moreover to determine the change in the interaction between both journalists and public relations experts or other experts, it is also expedient to analyze the foreign experience of implementing the 'media catching' phenomenon and testing the media model, being invented and proposed by foreign media - practices. The model is based on the assumption most of the problems and opportunities are unpredictable, but the work skills acquire a special intensive, promising disclosure in such conditions, which leads to optimal results in development, creating all the necessary conditions for media sphere managing. Thus, it can be argued there is a need to make positive changes to the internal organizational component of content creation and to update the current issue importance.

Analysis of recent research. New media technologies have increased the modern studies number on both domestic media industry state and prospects. Thus, periodicals and scientific publications mostly contain a negative characteristic of domestic media, referring to numerous assessments of their activities effectiveness and the respondents' survey [5-9]. Works of Media Detector [10] and the Media Development Foundation (MDF) [11] are among the most qualitative developments of the above-mentioned issue, which unanimously argue there is no professional moderation of media work. Moreover, nowadays, the effective interconnection between business and other economic subjects or professional activity and domestic media is not established. The qualitative studies' development of the Ukraine media space is only gaining momentum, especially in the European integration framework and cross-border expert cooperation strengthening in the outlined sphere.

The objective of the study. The purpose of the material is to characterize the current mass media trends in Ukraine and to form a comprehensive picture of the media industry future prospects. In accordance with the set goal, the main tasks of the article were outlined: 1) to consider the legal basis of the modern media organizational work and to confirm all the main problem issues; 2) analyze the intensification of 
the fake content distribution; 3) analyze the 'media-catching' phenomenon and characterize the influence of the media VUCA concept [12] to improve the current media sphere in Ukraine; 4) to formulate conclusions and develop author's proposals for the online segment and print media development in Ukraine, based on the study results.

The main research material presentation. Taking into account the information inequality, the problem of economic-technical, cultural-psychological and other barriers availability in accessing media products variability and perspectives created by the latest information and communication technologies is being actualized. Such tendencies lead to a lack of alternatives, a wide choice of media content, making the audience dependent on unified, popular media products. The following questions arise more and more frequently: how methodologically correct media owners are approaching the media content development, whether they are guided by the strategy of a potential (planned) target audience - a real audience; how they organize and control processes; do they study the media needs of the audience, or consider advertising as a factor, being able to determine the content and prospective audience from the start, or participate in the editorial process construction?

Today there is also a problem of media research (mediametry) imperfection in the researchers' sphere: media both do not have the appropriate KPI (quantitative norm of non-plagiary articles per person) and do not properly study all the human media needs that leads to non-objective data on its real interests, tastes, wishes [13, p. 98].
Marketing imperatives make media organizations holders adapt solely to the advertisers requirements. More and more journalists are leveraging the information sources quality, mostly trying to 'pull out' the new data, at least investing in it on the 'fast food' principle, without paying any attention to the context, quality and truth of the content [14, p. 197].

Unfortunately, in Ukraine, we can observe the daily increase of the socalled 'fake news' that involve completely or partially fictional information about events, phenomena, certain persons. We should also note that the phenomenon of such information originates from ancient times, but today it is striking by its mass and not controllability. The main feature of 'fake news' is the lack of variety of messages and synchronous distribution at once through all available channels. An example of "fake news" may be the dissemination on November 29, 2018 of the information that syringes, bandages and IVs will disappear from the store shelves in connection with the adoption of amendments to the Law of Ukraine "On Medicinal Products" [15]. Representatives of StopFake analyzed the bill and proved that there was no mention of such changes [16]. It should be noted that in this case, the media referred to the "authoritative opinion of pharmacists" in order to "capture" the audience. Given the geopolitical tensions related to Ukraine, the number of "fake news" began to increase in geometric progression. Following example illustrates the presence in the Ukrainian news stream of artificial news, especially produced with the real support of the pro-Russian media: Media dissemi- 
nated information that Sumy region, in which the martial law was introduced, local residents began to receive text messages demanding that they immediately come to the military commissariat [17]. This kind of dissemination of information is definitely "fake" and has nothing to do with the Ministry of Defense of Ukraine and mobilization, however, caused panic among the residents of the region regardless.

It is worth emphasizing that domestic legislation does not punish the distribution of "fake news", only contains a reference to the illegality of the distribution of unconfirmed information. Moreover, at the legislative level, the existence of such news in the territory of our state has not even been recognized and their features are not distinguished. The immediate process of prosecution is rather complicated in view of the need for the injured party to appeal to the competent authorities, in turn, the media distribute the content to the general public and are rarely held responsible. Recently, it was suggested that a draft law on countering "fakes" be drawn up, however, such a proposal received significant criticism, especially given the decriminalization of the defamation. The Committee on Freedom of Speech and Information Policy of the Ukrainian parliament noted that the adoption of such a law would be a step backwards for the rights of journalists [18]. It is necessary to agree with this statement, because such responsibility can become a tool to influence on the media. However, the current situation requires the adoption of measures and making of decisions. The need to counter "fakes" by the journalists themselves has been repeatedly emphasized. In this context, the following actions are advised to counteract such fake information: 1) strengthening control over the correspondence between the duties and skills of the editorial staff; 2) strengthening control over the organization of the editorial process; 3) standardization, regulation of the main processes of the editorial staff; 4) permanent consulting support, etc.

Of course, the modern stage of development of our state requires radical changes in all spheres of its existence, including the media. The concept of marketing is a scientifically sound project of organizing the activities of mass media in general or of its marketing activity in particular, based on a specific management idea, effective strategy, which is aimed at achieving results. The not-too-high level of domestic journalism, secrecy from the marketing component and the over-saturation of the media space by low quality content lowers the level of trust in domestic media. Thus, the Reuters Institute for the Study of Journalism at Oxford University published a Report on Understanding the Reasons for Growth and Decreasing Media Confidence [19], but Ukraine could not even enter neither the world nor the European media rating due to its low actual levels.

Therefore, the issue of creating a high-quality, audience oriented and content-rich content remains relevant, especially given the ineffectiveness of selected management techniques for the competitive product creation in the media market. In particular, the following negative trends of the media industry in Ukraine were identified: 1) shrinkage of the media market in view of negative demographic proces- 
ses and the recognition of a paramilitary conflict; 2) the outflow from media to social networks; 3) insufficient quantity of domestic quality content; 4) low competitiveness of regional mass media; 5) "cloning" of media products, which leads to the same content being reproduced [20]; 6) lack of profitability, staying on the brink of "survival" due to lack of skills and balance within the team, etc. Overall there is a trend for domestic journalism to produce the content of decreasing quality with decreasing efficiency, as a result we observe the loss of reputation that was built over the years. The phenomenon of hyperlocal media as a stable business platform is not currently getting adequate support, the desire to increase the internal efficiency of the media remains unfulfilled, there is still a significant lack of knowledge (do not know how to do) and lack of motivation for change (unable to think clearly for 6-24 months ahead). The revealed trends give an impetus for further reflection on the causes and consequences of such a situation in the media space and the possibilities of effective solution of the outlined issues. Discussions related to the prospects of using marketing mechanisms in the media sphere are currently being actively pursued. The revealed trends give an impetus for further reflection on the causes and consequences of such a situation in the media space and the possibilities of effective solution of the outlined issues. Discussions related to the prospects of using marketing mechanisms in the media sphere are currently being actively pursued.

The given context necessitates the establishment of links between the standards of journalism with the domestic law regulating media activities. Modern globalization reduces the role of national legislation in the context of the expansion of various information flows. Such freedom primarily affects the content, the creation of which today goes beyond any legislative, technological and, in the end, ethical limits established in our society and the state. Content management is complicated by the reluctance of teams (and editors) to apply new knowledge and be open to communication. In the context of globalization, the idea of developing common laws and principles of governance is closest in its essence to controlling the content of the media and regulating their internal organizational activities.

Currently, the laws regulating organizational processes of content creation are recognized as archaic and devoid of the marketing component essential for domestic media market players. The legal basis for the activities of domestic media is defined by the Constitution of Ukraine [21], Law of Ukraine dated 02.10.1992 № 2657-XII "On Information" [22], dated November 16, 1992, № 2782-XII “On the Printed Media (Press) in Ukraine" [23], dated February 28, 1995, № 74/95-VR “On Information Agencies" [24], dated September 23, 1997 № 539/97-VR “On the Procedure for Covering the Activities of Public Authorities and Local Authorities in Ukraine by the Mass Media" [25], dated December 21, 1993, № 3759-XII "On Television and Radio Broadcasting" [26], dated September 23, 1997 № 540/97-VR “On State Support to Mass Media the information and social protection of journalists" 
[27] and other norms of the current legislation of Ukraine.

In particular, the Law of Ukraine "On Printed Media (Press) in Ukraine" contains Section II, which regulates the organization of the activities of print media. The provisions of this legal act establish two types of guidance documents in determining the organizational component - a program of activities of the printed media and the statute of the editorial office. However, there is no provision for any detail or direct reference to marketing concepts and their approbation.

The Law of Ukraine "On Television and Radio Broadcasting" defines the organizational conditions for the functioning of this type of media. In particular, it is rather interesting to to see a provision of the law necessitating the adoption of an editorial charter of teleorganization, which defines, among other things, the basic requirements for ensuring the accuracy, objectivity, impartiality and balance of information disseminated by the broadcasting organization; requirements for verifying the authenticity of information received from third parties, etc. In addition, it provides for the creation of a special body responsible for monitoring compliance with the provisions of the bylaws.

The Law of Ukraine "On Information" in Article 23 consolidates the definition of the term "information products", but does not provide any requirements for information activities regarding their development by the mass media.

All others of the specified and analyzed legal acts do not even contain indirect references to the structure, prin- ciples, characteristics and requirements of the internal organization of the work of the media, or any professional qualification requirements for media executives. Thus, it can be stated that despite the negative trends of reduction of the quality of media content, clear requirements for the organization of the media, capable of changing the existing trend, are not enshrined in the current legislation. Legislative norms give all the power to regulate the media's internal activities to media owners, who are currently mostly neglecting positive marketing and management practices.

The functioning of the media in market realities requires the development of a comprehensive state strategy for reforming the domestic media industry. With the adoption of the Law of Ukraine dated December 24, 2015, № 917-VIII "On reforming state and communal print media" [28], the reform of state and municipal print media has started, however, given the unsettled nature of such a process, substantial changes have not yet been made. Media work slower than the market conditions allow, incur unnecessary costs.

It should be emphasized that the ratification and entry into force of the Association Agreement between Ukraine, on the one hand, and the European Union, the European Atomic Energy Community and their Member States, on the other hand (dated 21.03.2014 and 27.06.2014) [29] have led to the excessive expectations in the field of European-oriented media transformation. Especially given that the Association Agreement stipulates the framework of cooperation on the subject of training of journalists and other media workers for both printed and electronic 
publications. This is done in order to provide support for the media (public and private) and to reinforce their independence, professionalism and links with European media in accordance with European standards, in particular stipulated by the Council of Europe (part 2 of article 396).

It should be emphasized that in fact, 4 years after the signing of this international Agreement, no effective changes have taken place, and the provisions of the Agreement in this area remain declarative. Moreover, the Plan of Measures to Implement the Association Agreement between Ukraine, on the one hand, and the European Union, the European Atomic Energy Community and their Member States, on the other hand, was approved by the Resolution of the Cabinet of Ministers of Ukraine dated October 25, 2017 [30], envisages bringing in line with the EU law the rules and standards for the provision of audiovisual media services and for the improvement of the skills of media professionals by 01.09.2019 only; transposing the provisions of the European Convention on Transfrontier Television and Directive 2007/65 / EC (as amended by Directive 2010/13 / EC) [31], while neglecting the need to address the issues outlined above. Consequently, the European integration areas of improving the media space of Ukraine will only affect television, which indicates the mediocrity and fragmentation of European integration tendencies, and could also affect printed and online media.

Comparative analysis with successful foreign practices suggests that it could be reasonable to take into account the commercial factor in the functioning of the media. It is also important to consider the need for organizing and controlling the mechanisms of forming the internal work of the industry, which is directly related to the latest business trends and the introduction of marketing approaches. Media have commercialized and started to become a market player, which involves competition, pricing, promotion of content in the media market, and, accordingly, is guided by marketing strategies, which in turn contribute to the development of effective ways to improve the quality of media work. For the most part, the media industry neglects the use of proven "media-catching" [32]. This may not be the most recent phenomenon, but innovative technologies and social networks have transformed it into a trend that helps increasing the efficiency of planning and the quality of management decisions. Therefore, "media catching" is a necessary component of media work for the long term. It should be emphasized that in this sense, the earlier mentioned concept of the VUCA [12] is worthy of consideration as one of the most promising areas, as a way to become relevant, internally organized and disciplined, effective and popular media.

Conclusion and prospects for further research. The low level of building an effective team to product the content by the national media is increasingly affecting the level of public confidence to the published information and to the media in general, that in its turn reduces the profitability of the entire industry. More and more, the regional media needs to obtain a financial basis for their future existence, and national reforms in this sector are only suppressing such a situation. Under these conditions, the media, for the most part, 
do not take into account the fact that firstly and foremost, they are business owners and require an internal, coherent, competitive process construction and planning to implement their own activities in the longer term, which in the current circumstances can raise the national media market to the European level. Insignificant marketing orientation, unstructured media, neglect of the key perfomance indicators, and the reluctance to introduce a foreign positive experience and an excessive amount (per thousand) - these are the leading factors of poor quality of the content. If decisive actions are not taken today, the national media industry will be doomed to decline.

Taking into account the abovementioned information, it is reasonable to propose the following steps to increase the prestige of the Ukrainian media in the European and world media services market, as a result of making the country more attractive and stories in business:

1. To organize effectively the internal work of the media by using marketing trends and the latest innovative technologies, including using well-known research results and other recommendations from experts with practical experience.

2. To tighten control over the quality of content from editors.

3. To conduct a qualitative factchecking and struggle with fake news.

4. To make media catching an integral part of internal media processes and to develop individual KPI's for each editor.

5. To take an active part in formation of laws and increase cooperation with European experts in the media industry.
All these steps will improve the professional competence in journalism and the prestige of the entire national media system.

\section{REFERENCES}

1. Spetsialnyi zvit "Stan zhurnalistskoi osvity na fakultetakh zhurnalistyky v Ukraini" [Special report "The state of journalistic education at the faculties of journalism in Ukraine”]. (2016). Kyiv: Detektor media [in Ukrainian].

2. Stelmakhova O. (2018). Yak pratsiuie media-ketching i shcho robyty iz yakistiu zhurnalistyky [How does media catching work and what to do with the quality of journalism]. nachasi. com. Retrieved from https://nachasi. com/2018/08/21/yak-pratsyuye-media-ketchyng [in Ukrainian].

3. Oliinyk E., Zaslavsky E., Parusinski J. (2018). Independent regional media: a fragile existence. mediadevelopmentfoundation.org. Retrieved from https://mediadevelopmentfoundation.org/analyses/ [in English].

4. Horska K. (2016). Mediakontent tsyfrovoi doby: transformatsii ta funktsionuvannia [Media Context of the Digital Age: Transformation and Functioning]. Doctor's thesis. Kyiv: Taras Shevchenko National University of Kyiv [in Ukrainian].

5. Zinchenko L. (2017). V Ukraini nemaie yakisnoi zhurnalistyky, bo suspilstvo do nei ne hotove [There is no qualitative journalism in Ukraine, because society is not ready for it]. detector.media. Retrieved from https://detector.media/infospace/ article/131600/2017-11-05-vukraini-nemae-yakisnoi-zhurnalistiki-bo-suspilstvo-do-nei-ne-gotove/ [in Ukrainian].

6. Kolodnytska S. (2018). Yakykh zhurnalistiv brakuie ukrainskym ZMI [What journalists lack Ukrainian me- 
dia?]. medialab.online. Retrieved from http://medialab.online/news/brakuje/ [in Ukrainian].

7. Pryshliak Ya. (2017). Zhurnalistyka maibutnoho: informatsiina chuma chy avanhard analityky? [Journalism of the future: information plague or vanguard of analysts?]. www.mediakrytyka.info. Retrieved from http:// www.mediakrytyka.info/onlayn-zhurnalistyka/zhurnalistyka-maybutnohoinformatsiyna-chuma-chy-avanhardanalityky.html [in Ukrainian].

8. Beckett C. (2018). Shcho take yakisna zhurnalistyka? [What is qualitative journalism?]. ua.ejo-online.eu. Retrieved from https://ua.ejo-online. eu/4219/etyka-ta-yakist/shcho-takeyakisna-zhurnalistyka [in Ukrainian].

9. Kabachii R. (2017). Uspishni media v Ukraini: nezdiisnenyi mif chy realnist [Successful media in Ukraine: unfulfilled myth or reality]. imi.org. ua. Retrieved from https://imi.org. ua/articles/uspishni-media-v-ukrajini-nezdijsnenyj-mif-chy-realnist/ [in Ukrainian].

10. Ofitsinyi sait Detector media [The official site of Detector media]. detector. media. Retrieved from https://detector.media/ [in Ukrainian].

11. The official site of Media Development Foundation (MDF). mediadevelopmentfoundation.org. Retrieved from https://mediadevelopmentfoundation.org [in English].

12. Volatility, uncertainty, complexity and ambiguity in Wikipedia. Retrieved from https://en.wikipedia.org/wiki/ Volatility,_uncertainty,_complexity_ and_ambiguity [in English].

13. Afañasieva (Horska) K. (2016). Typolohiia mediakontentu za kryteriiem roli avtora [Typology of media content by criterion of the author's role]. Tele- ta radiozhurnalistyka - TV and radio journalism, 15, 96-102 [in Ukrainian].
14. Pocheptsov H. (2015). Suchasni informatsiini viiny [Modern Information Warfare]. Kyiv: Kyievo-Mohylianska akademiia [in Ukrainian].

15. Farmatsevty: Vlasti khotyat ostavit ukraintsev bez shpritsov i bintov [Pharmacists: The authorities want to leave the Ukrainians without syringes and bandages]. (2018). ukraina. ru. Retrieved from https://ukraina. $\mathrm{ru} /$ news/20181118/1021791055.htm 1?fbclid=IwAR2TVNT0TRJNwpCM OJ7TKN1KyP0t_yhN5cvZzr0Z6As3Wz0Gp4OnuF4rcX0 [in Russian].

16. Feik: Ukraintsiv zalyshat bez shprytsiv i byntiv [Fake: Ukrainians will be left without syringes and bandages]. (2018). www.stopfake.org. Retrieved from https://www.stopfake.org/uk/ fejk-ukrayintsiv-zalishat-bez-shpritsiv-i-bintiv/ [in Ukrainian].

17. RF zbilshyla kilkist feikovykh novyn cherez vvedennia viiskovoho stanu v Ukraini - Minoborony [Russia has increased the number of fake news because of the introduction of Martial law in Ukraine - the Ministry of Defense]. www.unian.ua. Retrieved from https://www.unian.ua/ society/10355988-rf-zbilshila-kilkistfeykovih-novin-cherez-vvedennyaviyskovogo-stanu-v-ukrajini-minoboroni.html [in Ukrainian].

18. Dmytruk A. (2018). Komitet z pytan svobody slova vidkynuv mozhlyvist kryminalizatsii poshyrennia feikiv [The Committee on Freedom of Speech rejected the possibility of criminalizing for distribution of fakes]. hromadske.ua. Retrieved from https://hromadske.ua/ posts/komitet-z-pytan-svobody-slovavidkynuv-mozhlyvist-kryminalizatsiiposhyrennia-feikiv [in Ukrainian].

19. Digital News Report (n.d.). www. digitalnewsreport.org. Retrieved from http://www.digitalnewsreport. org/survey/2018/analysis-by-country-2018/ [in English]. 
20. Kontseptsiya. Mart - 2018 [Concept. March - 2018]. (n.d.). www.deadline. com.ua. Retrieved from https://www. deadline.com.ua/frontend/web/design/deadline_CONC_march2018. pdf [in Russian].

21. Konstytutsiia Ukrainy : vid 30.09.2016, № 1401-VIII [The Constitution of Ukraine from 30.09.2016, № 1401-VIII]. (n.d.). zakon.rada.gov. ua. Retrieved from http://zakon.rada. gov.ua/laws/show/254\%D0\%BA/96$\% \mathrm{D} 0 \% \mathrm{~B} 2 \% \mathrm{D} 1 \% 80$ [in Ukrainian].

22. Zakon Ukrainy "Pro informatsiiu" : vid 01.01.2017, № 1774-VIII [Law of Ukraine "On Information" from 01.01.2017, № 1774-VIII]. (n.d.). zakon.rada.gov.ua. Retrieved from http://zakon.rada.gov.ua/laws / show/2657-12 [in Ukrainian].

23. Zakon Ukrainy "Pro drukovani zasoby masovoi informatsii (presu) v Ukraini” : vid 04.11.2018, № 2581-VIII [Law of Ukraine "On printed mass media (press) in Ukraine” dated 04.11.2018, № 2581-VIII]. (n.d.). zakon.rada. gov.ua. Retrieved from http://zakon. rada.gov.ua/laws/show/2782-12 [in Ukrainian].

24. Zakon Ukrainy "Pro informatsiini ahentstva" : vid 21.05.2015, № 317VIII [Law on Informational Agencies dated 21.05.2015, № 317-VIII]. (n.d.). zakon.rada.gov.ua. Retrieved from http://zakon.rada.gov.ua/laws/ show $/ 74 / 95-\%$ D0\%B2\%D1\%80 [in Ukrainian].

25. Zakon Ukrainy "Pro poriadok vysvitlennia diialnosti orhaniv derzhavnoi vlady ta orhaniv mistsevoho samovriaduvannia v Ukraini zasobamy masovoi informatsii" : vid 21.10.2018, № 2578-VIII [Law of Ukraine "On the Procedure for Covering the Activities of Public Authorities and Local SelfGovernment Bodies in Ukraine by the Mass Media" dated 21.10.2018, № 2578-VIII]. (n.d.). zakon.rada. gov.ua. Retrieved from http://zakon. rada.gov.ua/laws / show/539/97 $\% \mathrm{D} 0 \% \mathrm{~B} 2 \% \mathrm{D} 1 \% 80$ [in Ukrainian].

26. Zakon Ukrainy "Pro telebachennia i radiomovlennia" : vid 04.11.2018, № 2581-VIII [Law of Ukraine "On Television and Radio" dated 04.11.2018, № 2581-VIII]. (n.d.). zakon.rada. gov.ua. Retrieved from http://zakon. rada.gov.ua/laws/show/3759-12 [in Ukrainian].

27. Zakon Ukrainy "Pro derzhavnu pidtrymku zasobiv masovoi informatsii ta sotsialnyi zakhyst zhurnalistiv" : vid 13.10.2018, № 2544-VIII [Law of Ukraine "On State Support to Mass Media and Social Protection of Journalists" dated 13.10.2018, № 2544-VIII]. (n.d.). zakon.rada. gov.ua. Retrieved from http://zakon. rada.gov.ua/laws/show/540/97$\% \mathrm{D} 0 \% \mathrm{~B} 2 \% \mathrm{D} 1 \% 80$ [in Ukrainian].

28. Zakon Ukrainy "Pro reformuvannia derzhavnykh i komunalnykh drukovanykh zasobiv masovoi informatsii” : vid 21.10.2018, № 2578-VIII [Law of Ukraine "On the reformation of state and communal print media dated 21.10.2018, № 2578-VIII]. (n.d.). zakon.rada.gov.ua. Retrieved from http://zakon.rada.gov.ua/laws/ show/917-19 [in Ukrainian].

29. Association agreement between the European Union and its Member States, of the one part, and Ukraine, of the other part. (2014). eeas.europa.eu. Retrieved from https://eeas.europa. eu/node/10420_en [in English].

30. Postanova Kabinetu Ministriv Ukrainy "Pro vykonannia Uhody pro asotsiatsiiu mizh Ukrainoiu, z odniiei storony, ta Yevropeiskym Soiuzom, Yevropeiskym spivtovarystvom Z atomnoi enerhii i yikhnimy derzhavamy-chlenamy, z inshoi storony" : vid 25 zhovtnia 2017, № 1106 [Resolution of the Cabinet of Ministers of Ukraine "On the implementation of 
the Association Agreement between Ukraine, of the one part, and the European Union, the European Atomic Energy Community and their Member States, of the other part, dated October 25, 2017, № 1106]. (n.d.). www.kmu.gov.ua. Retrieved from https://www.kmu.gov.ua/ua/npas/ pro-vikonannya-ugodi-pro-asociaciyu-mizh-ukrayinoyu-z-odniyeyi-storoni-ta-yevropejskim-soyuzom-yevropejskim-spivtovaristvom-z-atomnoyi-energiyi-i-yihnimi-derzhavami-chlenami-z-inshoyi-storoni [in Ukrainian].

31. Directive $2007 / 65 /$ EC of the European Parliament and of the Council of 11 December 2007 amending Council Directive $89 / 552 /$ EC on the coordination of certain provisions laid down by law, regulation or administrative action in Member States concerning the pursuit of television broadcasting activities (2007). Official Journal of the European Union. Retrieved from https://www.wipo.int/wipolex/ru/ text.jsp?file_id=199630 [in English].

32. Waters, R. D., Tindall, N. T. J., \& Morton, T, S. (2010). Media catching and the journalist-public relations practitioner relationship: How social media are changing the practice of media relations. Journal of Public Relations Research, 22(3), 241-264. Retrieved from https://www.researchgate.net/publication/232865093_Media_Catching_and_the_Journalist-Public_Relations_Practitioner_Relationship_ How_Social_Media_are_Changing_ the_Practice_of_Media_Relations [in English].

\section{СПИСОК ВИКОРИСТАНИХ ДЖЕРЕЛ}

1. Детектор медіа (2016), “Стан журналістської освіти на факультетах журналістики в Україні (результати пілотного дослідження)”, Спеціальний звіт, Київ, Ukraine.

2. Стельмахова О. (2018), “Як працює медіа-кетчінг і що робити із якістю журналістики", available at: https://nachasi.com/2018/08/21/ yak-pratsyuye-media-ketchyng/ (Accessed 4 December 2018).

3. Oliinyk E. Zaslavsky E., Parusinski J. (2018), "Independent regional media: a fragile existence”, available at: https:// mediadevelopmentfoundation.org/ analyses/ (Accessed 4 December 2018).

4. Горсъка К. (2016) "Медіаконтент цифрової доби: трансформації та функціонування”, Doctor dissertation, Sociological Sciences, Taras Shevchenko National University of Kyiv, Kyiv, Ukraine.

5. The official site of Detector media (2017), “В Україні немає якісної журналістики, бо суспільство до неї не готове”, available at: https:// detector.media/infospace/article/ 131600/2017-11-05-v-ukraini-nemaeyakisnoi-zhurnalistiki-bo-suspilstvodo-nei-ne-gotove/ (Accessed 4 December 2018).

6. The official site of Medialab (2018), "Яких журналістів бракує украінським 3MI”, available at: http:// medialab.online/news/brakuje/ (Accessed 4 December 2018).

7. The official site of Mediakrytyka (2018), “Журналістика майбутнього: інформаційна чума чи авангард аналітики?”, available at: http://www.mediakrytyka.info/ onlayn-zhurnalistyka/zhurnalistykamaybutnoho-informatsiyna-chumachy - avanhard - analityky. ht m l (Accessed 4 December 2018).

8. The official site of European Journalism Observatory (2018), “Шо таке якісна журналістика?”, available at: https://ua.ejo-online.eu/4219/ etyka-ta-yakist/shcho-take-yakisna- 
zhurnalistyka (Accessed 4 December 2018).

9. The official site of Institute Mass Information (2017), "Успішні медіа в Україні: нездійснений міф чи реальність?”, available at: https:// imi.org.ua/articles/uspishni-mediav-ukrajini-nezdijsnenyj-mif-chy-realnist / (Accessed 4 December 2018).

10. The official site of Detector media (2018), available at: https://detector. media / (Accessed 4 December 2018).

11. The official site of Media Development Foundation (MDF). (2018), available at: https://mediadevelopmentfoundation.org (Accessed 4 December 2018).

12. The official site of Wikipedia (2018), "Volatility, uncertainty, complexity and ambiguity", available at: https:// en.wikipedia.org/wiki/Volatility,_uncertainty,_complexity_and_ambiguity (Accessed 4 December 2018).

13. Афанасьвва (Горська) К. (2016), “Типологія медіаконтенту за критерієм ролі автора" // Теле- та радіожурналістика. - Т. 15. - С. 96-102.

14. Почепщов Г. (2015), "Сучасні інформаційні війни”, Києво-Могилянська академія, Київ, Україна.

15. The official site of Украина.py (2018), "Фармацевты: Власти хотят оставить украинцев без шприцов и бинтов", available at: https://ukraina. $\mathrm{ru} /$ news/20181118/1021791055. html?fbclid=IwAR2TVNT0 TRJ $\mathrm{N}$ w p C M O J 7 T K N 1 K y P 0 t yhN5cvZzr0Z6As3Wz0Gp4Onu F4rcX0 (Accessed 4 December 2018).

16. The official site of StopFake (2018), "Фейк: Українців залишать без шприців i бинтів”, available at: https://www.stopfake.org/uk/fejkukrayintsiv-zalishat-bez-shpritsiv-ibintiv/ (Accessed 4 December 2018).

17. The official site of Unian (2018), "РФ збільшила кількість фейкових новин через введення військового стану в Україні - Міноборо- ни", available at: https://www.unian. ua/society/10355988-rf-zbilshilakilkist-feykovih-novin-cherezvvedennya-viyskovogo-stanu-vukrajini-minoboroni.html (Accessed 4 December 2018).

18. The official site of Громадське Телебачення (2018), "Комітет з питань свободи слова відкинув можливість криміналізації поширення фейків", available at: https://hromadske. ua/posts/komitet-z-pytan-svobodyslova-vidkynuv-mozhlyvist kryminalizatsii-poshyrennia-feikiv (Accessed 4 December 2018).

19. The official site of Reuters Institute (2018), Digital News Report, available at: http://www.digitalnewsreport.org/survey/2018/analysis-bycountry-2018/ (Accessed 4 December 2018).

20. The official site of Deadline (2018), "Концепция. Март - 2018", available at: https://www.deadline.com. ua/frontend/web/design/deadline CONC march2018.pdf (Accessed $\overline{4}$ December 2018).

21. The Verkhovna Rada of Ukraine (1996), The Law of Ukraine "Конституція України", available at: http://zakon.rada.gov.ua/ laws / show / $254 \%$ D $0 \%$ B A / 96 $\% \mathrm{D} 0 \% \mathrm{~B} 2 \% \mathrm{D} 1 \% 80$ (Accessed 4 December 2018).

22. The Verkhovna Rada of Ukraine (1992), The Law of Ukraine "Про інформацію", available at: http://zakon.rada.gov.ua/laws/show/2657-12 (Accessed 4 December 2018).

23. The Verkhovna Rada of Ukraine (1992), The Law of Ukraine "Про друковані засоби масової інформації (пресу) в Україні”, available at: http://zakon.rada.gov.ua/laws/ show/2782-12 (Accessed 4 December 2018).

24. The Verkhovna Rada of Ukraine (1995), The Law of Ukraine "Про 
інформаційні агентства”, available at: http://zakon.rada.gov.ua/laws/ show $/ 74 / 95-\%$ D0\%B2\%D1\%80 (Accessed 4 December 2018).

25. The Verkhovna Rada of Ukraine (1997), The Law of Ukraine "Про порядок висвітлення діяльності органів державної влади та органів місцевого самоврядування в Україні засобами масової інформаціï, available at: http://zakon.rada.gov.ua/laws/ show $/ 539 / 97-\%$ D0\% B2\%D1\%80 (Accessed 4 December 2018).

26. The Verkhovna Rada of Ukraine (1993), The Law of Ukraine "Про телебачення і радіомовлення”, available at: http://zakon.rada.gov.ua/ laws/show/3759-12 (Accessed 4 December 2018).

27. The Verkhovna Rada of Ukraine (1997), The Law of Ukraine "Про державну підтримку засобів масової інформації та соціальний захист журналістів”, available at: http://zakon.rada.gov.ua/laws/show/540/97$\% \mathrm{D} 0 \% \mathrm{~B} 2 \% \mathrm{D} 1 \% 80$ (Accessed 4 December 2018).

28. The Verkhovna Rada of Ukraine (2015), The Law of Ukraine "Про peформування державних і комунальних друкованих засобів масової інформаціi”, available at: http://zakon. rada.gov.ua/laws/show/917-19 (Accessed 4 December 2018).

29. The official site of European Union (2014), "Association agreement between the European Union and its Member States, of the one part, and
Ukraine, of the other part", available at: https://eeas.europa.eu/node/10420 en (Accessed 4 December 2018).

30. Cabinet of Ministers of Ukraine (2017), “План Заходів з виконання Угоди про асоціацію між Україною, з однієї сторони, та Свропейським Союзом, Свропейським співтовариством 3 атомної енергії і іхніми державами-членами, з іншої сторони”, available at: https://eu-ua.org/ plan-zakhodiv-z-vykonannia-uhody (Accessed 4 December 2018).

31. European Parliament and Council (2007), "Directive 2007/65/EC of the European Parliament and of the Council of 11 December 2007 amending Council Directive 89/552/EC on the coordination of certain provisions laid down by law, regulation or administrative action in Member States concerning the pursuit of television broadcasting activities", available at: https://www.wipo.int/wipolex/ru/ text.jsp?file_id=199630 (Accessed 4 December $\overline{2018)}$.

32. Moyer J. (2012) "Media catching and the journalist-public relations practitioner relationship: how social media are changing the practice of media relations", available at: https://www.researchgate.net/publication/232865093_Media_Catching_and_the_Journalist-Public_Relations_Practitioner_Relationship_ How_Social_Media__are_Changing_ the_Practice_of_Media_Relations (Accessed 4 December 2018). 